ISSN 2078-6441. Вісник Львівського університету. Серія географічна. 2013. Випуск 44. С. 215-227. Visnyk of the Lviv University. Series Geography. 2013. Issue 44. P. 215-227.

551.8. 631.4.902. 477.53

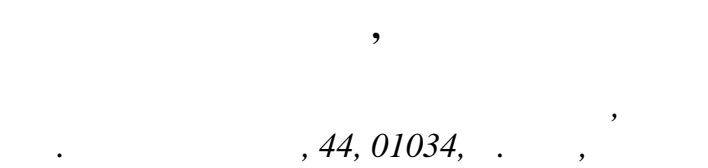

ростежено розвиток грунтів н невеликій з площею території в меж $\mathrm{x}$ рхеологічного об'єкт . ля дослідження з стосов но п леопедологічний метод з використ нням мікроморфологічного н лізу. исновки стосуються особливостей розвитку грунту в пізньому плейстоценіголоцені.

лючові слов : грунт, генезис, п леопедологічний метод, плейстоцен, голоцен.

икопні грунти необхідно сприйм ти не просто як свідки фізико-геогр фічних умов утворення; вони в стр тигр фічному розрізі відобр ж ють ритм змін цих умов. одо товщ суб ер льного походження (лесових покривів) викопні грунти, як н голошено, $є$ яскр вими свідк ми безперервно-переривного процесу їхнього розвитку. тже, як свідчення перерв бо сповільненого н копичення суб ер льних лесових порід, пов'яз них зі ст новленням певного типу фізико-геогр фічних умов н великих територіях, викопні грунти для дослідників розвитку грунтового покриву н був ють зн чення в жливих м ркув льних горизонтів.

серпні 2012 р. співробітники нституту геогр фії кр їни дослідили могильник черняхівської культури III-IV ст. оботи проводили у скл ді рхеологічної експедиції нституту рхеології кр їн під керівництвом к нд. іст. н ук . ейди. ей рхеологічний об'єкт розміщений поблизу смт иш ки олт вської обл. охов ння розт шов ні в меж х піщ ного к р'єру (площ - близько 2 г ), н південно3 хідній його окр їні, з 1 км від д мби н території вододілу (див. рис. 1, г).

б’єктом дослідження були викопні грунти в розчистк х, що розт шов ні в меж х рхеологічного об'єкт . озчистк $1 \epsilon$ основним розрізом з ртеф кт ми черняхівської культури, розчистк 2 - фоновий розріз, розміщений н ідентичному геоморфологічному рівні, у протилежній стінці к р'єру, досліджено т кож верхньоплейстоценові відкл ди к р’єру.

икон ний дет льний м кроморфологічний опис обох розчисток, т кож мікроморфологічний н ліз грунту під мікроскопом у тонких зріз х 0,02-0,04 м.

етодик дослідження викопних грунтів тісно з лежить від поглядів н їхню природу, походження, поширення, н укове т пр ктичне зн чення.

окрему ув гу з слуговують пр ці щодо грунтів укр їнської п леогеогр фічної школи під керівництвом . еклич. ентром 3 вивчення пізньок йнозойських викопних грунтів в кр їні вв ж ють сектор геогр фії нституту геологічних н ук , у якому пр цюв ли, окрім . еклич, т кож . іренко, . урло, . убняк, . твї̈шин, . ер сименко, . рпенко, . ередерій т ін. гомий внесок у розвиток п леопедологічних досліджень зробили предст вники інших

(C) твіїшин ., ушнір ., 2013 
уст нов - . ожик, . овкопляс, . іренко, . озгрін, . еклич, . д менко,

. родецьк, . езусько, . огуцький, . униця, . митрук т ін.

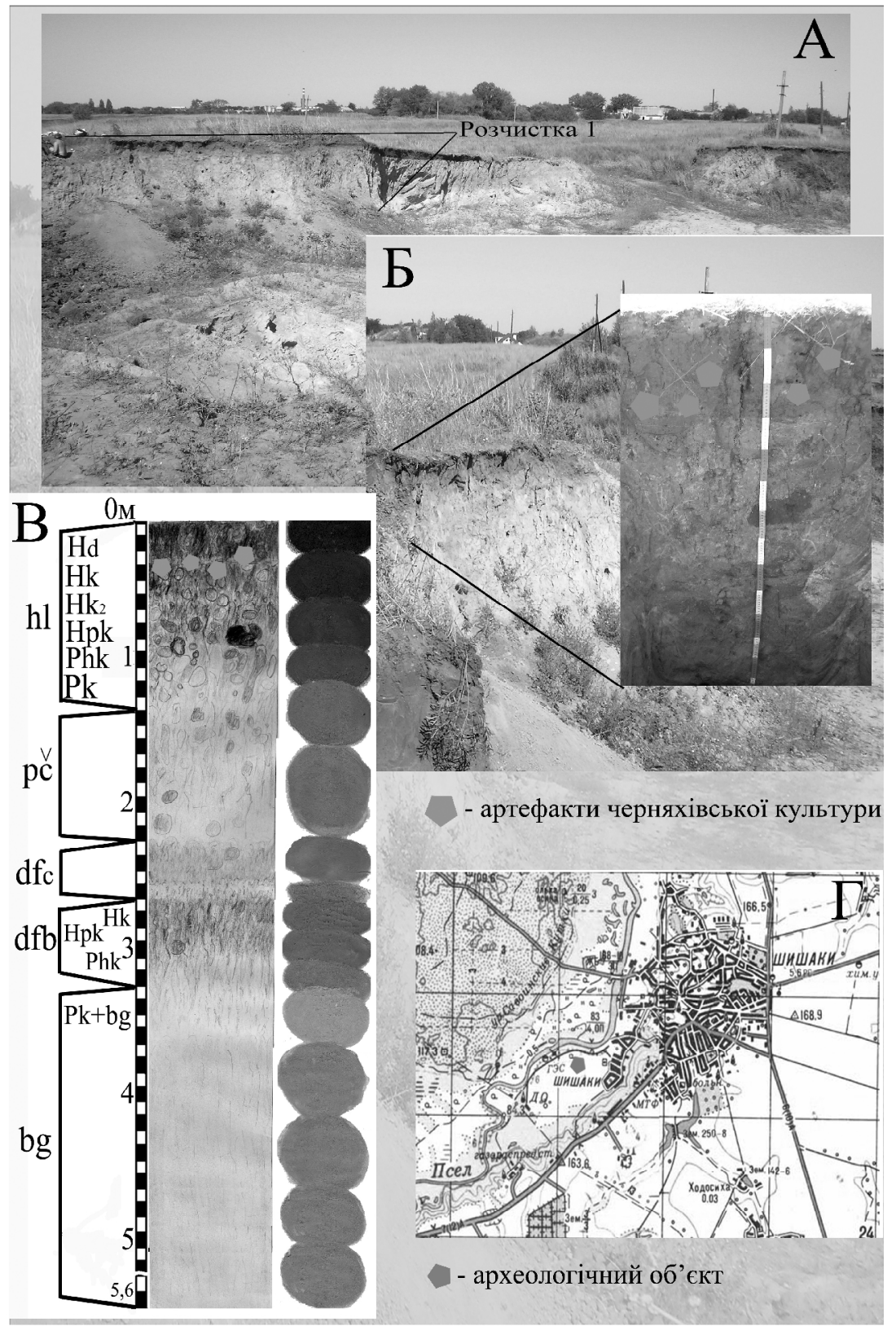

ис. 1. иш ки 2012. огильник черняхівської культури. - місце розт шув ння розчистки 1; - 3 г льний вигляд положення профілю грунту в розчистці $1 ;-$ м сшт бн польов $з$ рисовк з прим зк ми природного м тері лу; - к ртосхем розт шув ння місця дослідження. 
суч сній грунтозн вчій н уці, як 3 йм ється перш 3 все поглибленням теоретичних і пр ктичних розробок з грунтозн вств і геогр фії грунтів у різних регіон х кр їни, окреме місце 3 йм $\epsilon$. озняк, який з колег ми вивч $є$ еволюцію грунтового покриву, геогр фічні з кономірності його поширення $\mathrm{T}$ методичні $\mathrm{i}$ методологічні з с ди грунтово-геогр фічних досліджень.

г лом методик досліджень викопних грунтів з снов н н принципі: викопні грунти потрібно вивч ти т к, Як вивч ють суч сні грунти. еобхідно п м'ят ти, що викопні грунти звич йно був ють зміненими под льшими ді генетичними процес ми, ун слідок чого вони н був ють нових рис будови, які ускл днюють процеси розпізн в ння їхньої первинної структури.

уже ефективним у р зі дослідження викопних грунтів п леопедологічним методом є мікроморфологічний н ліз, головне з вд ння якого поляг $є$ у вивченні будови (скл ду, текстури, грег тного ст ну, пористості) i речовинного скл ду (гумусу, високо- i грубодисперсної ч стин, новоутворень, включень) грунтів. сі зібр ні відомості д ють змогу з дост тнім обгрунтув нням виділяти генетичні типи грунтів - чорноземні, лісові, підзолисті, солонцюв ті т ін. ході дет льних досліджень викопних грунтів можн визн ч ти не тільки їхні основні генетичні типи, й підтипи. ирокого з стосув ння цей н ліз н був у пр цях . рюєр , . убієни, . еклич , . твіїшиної, . рилової, · рфьонової, . едвєдєв , . еліщевої, . ер симової, . орозової, . обровольського, - убін, . ргульян, . об, . урсін т ін.

ст нніми в жливими пр цями, що присвячені використ нню мікроморфологічного н лізу як скл дового п леопедологічних досліджень в кр їні, є дисерт ційні дослідження . рхоменк , . рм зиненк, . орошкевич , · л м рчук, які безсумнівно продовжили розвиток н пряму п леогеогр фічної школи . еклич т твіїшиної. ей вид н лізу використовують т кож у л бор торії ніпропертовського н ціон льного університету ім. леся онч $\mathrm{p}$. оботи проводяться під керівництвом . р влеєв , . ілової т . ковенко.

рунтові розрізи голоценових т плейстоценових грунтів ми досліджув ли т к: описув ли природно-геогр фічне положення розрізу, виконується дет льний м кроморфологічний опис грунту, виконув ли польову з рисовку розрізу з прим зк ми природного м тері лу, відбир ли зр зки для л бор торних досліджень з под льшою інтерпрет цією д них. ижче н ведено описи грунту з результ т ми мікроморфологічного н лізу. р зки грунту у шліф х з непорушеною будовою викон но 3 допомогою мікроскоп $\quad-8 \mathrm{~T} \quad-301$.

ш мет - визн чення основних особливостей генези грунтового покриву в окремі дрібні ет пи пізнього плейстоцену т голоцені.

оверхня віт чево-бузької (vt-bg) тер си, де розміщений об'єкт, плоск , з тр в'яним покривом, у якому перев ж є типч ково-ковилов рослинність з елемент ми ч г рників (див. рис. 1, ). ерія різноорієнтов них з сторон ми світу черняхівських похов нь, серед яких перев ж ють східної т з хідної, рідше південної орієнт ції, з ляг є н глибині близько $30 \mathrm{~cm}$ від поверхні. тже, можн робити висновок про те, що з ч с існув ння черняхівського могильник утворився грунтовий профіль потужністю 0,3 м. ей рхеологічний об'єкт цік вий тим, що з лишки м тері льної культури досить чітко д тов ні. леогеогр фічні дослідження об'єкТ проводять уперше. ивчений плейстоценовий розріз і дві розчистки грунту - плейстоценовий розріз порівняно 3 фоновим. 
ростежено т ку стр тигр фію відкл дів по всьому периметру к р'єру: суч сний грунт (hl) - потужністю до 1,3 м, темно-сірий до чорного, іноді ч стково зріз ний; причорноморський лес (рс̌) - до 1,5 м і більше, у невеличкій з п динці й по всьому к р’єру видно дві ст дії розвитку дофінівського (df) грунту, який змінює потужність з лежно від рельєфу, нижче н слідком холодної ст дії розвитку природи є - бузький лес (bg) з білястим к рбон тним ілювієм.

озчистк 1 розт шов н безпосередньо н площі рхеологічних досліджень. осить чітко простежується меж з культурним ш ром черняхівської культури у вигляді горизонт льної межі, одн к це т кож може бути лінія похов ння, т к що меж умовн . рофіль грунту включ є верхній, суч сний грунт 0,3 м потужністю і нижній, що існув в у ч си черняхівської культури (див. рис. 1, б).

верху вниз простежено т кі генетичні горизонти суч сного грунтового профілю:

Hd - 0,00-0,05 м - дернин , коричнюв тий до темно-сірого м тері л з корінцями тр в, перев жно зл кових, типч ку, деревію. ерехід і меж з зменшенням кількості корінців тр в;

к - 0,05-0,30 м - темно-сірий до чорного, у сухому ст ні сл бкоущільнений, у вологому пухкий, грудкув то-зернистий 3 чіткою структурою м тері л. елик кількість кротовин 6-7 см у ді метрі, з повнених темно-сірим м тері лом. нтенсивно переритий черв ми, з тонкими корінцями рослин. ипить з $10 \%$ розчином 1 , ле без видимих форм к рбон тів. ерехід і меж дуже чіткі у вигляді горизонт льної смуги, перехід помітний з освітленням з б рвлення і появою великої кількості к рбон тів у вигляді міцелію.

ід ч с вивчення під мікроскопом виявлено $m$ кі озн ки: пухке губч те скл дення, мікро грег ти другого-четвертого порядку, в основі яких - згустки і грудочки гумусу (екскременти червів). структурі перев жек $е$ бон тно-глинистий м тері $л$, просочений мікрокрист л ми к льциту, який бере уч сть у скл ді мікро грег тів. ельєф плоский, інтенсивно розвинут сітк звивистих між- $і$ внутрішньо грег тних

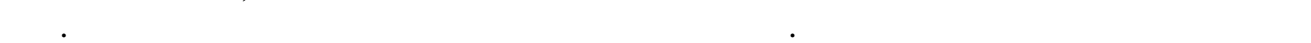
60-70\% площі шліф, головно ие крупно-пилув ті зерн кв риу з крбон тноглинистими оболонк ми. озміри -до 0,25 мм і більше (див. рис. 2, , б).

рунт зм тері льними рештк ми черняхівської культури.

$\mathrm{K}_{2}-0,3-0,6$ м - дещо світліший від того, що з ляг є вище, темно-сірий, однорідно з 6 рвлений, пухкий, крупно-грудкув то-зернистий, у сухому ст ні сл бкоущільнений. онизу структур ст є пухкішою. дзвич йно інтенсивно переритий землериями, кротовини з різнокольоровим м тері лом з повнення; це піщ но-пилув тий легкий суглинок з великою кількістю міцелярних т борошнистих форм к рбон тів по трішин х, ктивно кипить $310 \%$ розчином 1. ерехід і меж досить поступові 3 посвітлінням кольору, збільшенням кількості кротовин і менш інтенсивним проявом міцелярних к рбон тів. м тері лі з фіксов ні_ртеф кти черняхівської культури.

ході дослідження під мікроскопом простежено темно-буру м су з пилув топл змовою структурою, систем звивистих пор розділяє скл дні мікро грег ти третього-четвертого порядку, простежуються темні грудочки $і$ згустки гумусу копроліти, усі зерн мінер льного скелет м ють гумусові оболонки (див. рис. 2, в, г).

\footnotetext{
1 ут і н д лі мікроморфологічний опис н ведено курсивом.
} 

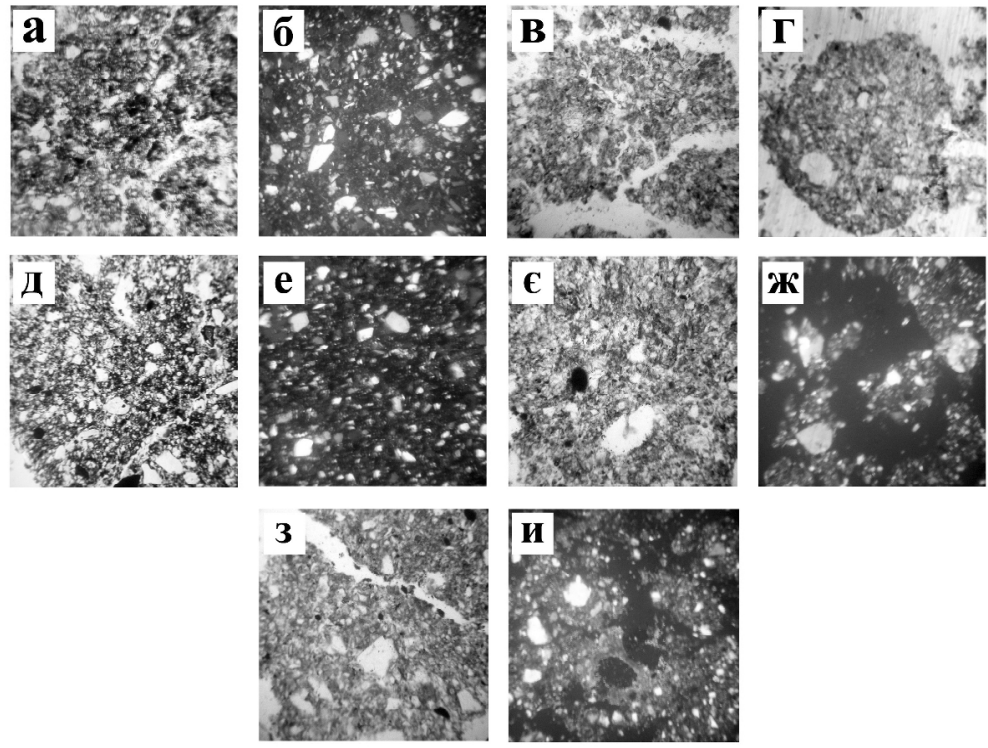

ис. 2. иш ки 2012. озчистк 1.

ікробудов суч сного грунту і грунту з ртеф кт ми черняхівської культури:

, $\sigma$ - гумусовий горизонт ( к) суч сного чорнозему: скл дні (до четвертого порядку) мікрогрег ти, сітк звивистих пор ( ), просочення пл зми мікрокрист лічним к льцитом (б); грунт 3 ртеф кт ми черняхівської культури: в - скл дні гумусово-к рбон тно глинисті мікро грег ти в гумусовому ( $\left.\mathrm{K}_{2}\right)$ горизонті; 2 - округлі к рбон тно-глинисті мікро грег ти; гумусовоперехідний горизонт ( рк): $\partial, e$ - ско гульов ний гумус, нечіткі скл дні мікро грег ти (д), просочення пл зми мікрокрист лічним к льцитом (e); перехідний горизонт (Phk):

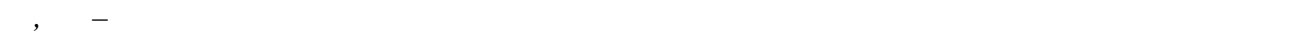
схрещених ніколях, розвинут сітк пор; к рбон тний ілювій: $e, i-$ освітлен і зцементов н мікрокрист лічним к льцитом пл зм, видно концентр цію мікрокрист лічного к льциту н вколо пор. б. 70, , в, г, д, ж, $e$ - нік. $\|, 6, e, ~ з, ~ u-$ нік. +.

рк - 0,60-0,84 м - сірий неоднорідно з б рвлений, з невеликими плям ми, явно світліш є донизу. ереритий землериями, ходи і к мери кротів 7-20 см у ді метрі, 3 повнені темно-сірим м тері лом з горизонту к, т кож п лево-сірим м тері лом 3 нижніх горизонтів. ухкий, грудкув то-зернисто-розсипч стий, піщ но-пилув толегкосуглинистий, кипить з $10 \%$ розчином 1. идно міцелярні форми к рбон тів, борошнисті виокремлення 3 3 3 корінцями рослин, що тр пляються по ход х і в житлових к мер х. е зн чно переритий землериями кротовинний горизонт. ерехід i меж досить поступові, простежують $з$ посиленням п левих відтінків 36 рвлення.

ід мікроскопом простежується темно-бур м с, мікро грег ти третьогочетвертого порядку, розділені системою звивистих пор, темні згустки гумусу рівномірно розсіяні у пл змі, у мінер льному скелеті поряд з пилом є великі зерн піску (див. рис. 2, $\partial, e$ ).

Phk - 0,84-1,10 м - сірув то-п левий, неоднорідно з $б$ рвлений, з великою кількість кротовин і ходів землериїв з п левим, сірим до темного-сірого кольору м тері лом 
3 повнення. іщ но-пилув тий легкий суглинок з грудкув то-розсипч стою структурою. онизу світліш $є$.

зр зк х з перехідного до породи горизонту у шліф х спрощені форми мікро грегов ності, збільшений вміст к рбон тів. с предст влен як скл дними, тк $i$ простими лесовими к рбон тно-глинистими сегрег ційними округлими мікро грег $m$ ми. ікрокрист лічний к льцит нерівномірно розподілений $у$ пл змі, утворює концентр ції, у тому числі н вколо пор від корінців рослин. інер льний скелет 70-80\% площі шліф, - скл дений перев жкно крупнопилув тими зерн ми, видно поодинокі піш, ні $m$ ул мкові зерн кв риу (див. рис. 2, є, ж).

к+pс̌ - 1,10-1,20 м - п левий до брудно-п левого колір м тері лу, пухкий, піщ нопилув тий легкий суглинок, структур розсипч ст , з к рбон т ми у формі просочень $\mathrm{i}$ трубочок.

ід мікроскопом м с м є пухку будову з вдяки вмісту великої кількості к рбон тів без орг ніки. тері л лесової будови. $\quad$ с скл ден к рбон тно-глинистими лесовими ч сточк ми, розділеними різної ширини звивистими пор ми. ростежуються концентр ції мікрокрист лічного $к$ льциту $у$ вигляді мікробілозірки. ерн мінер льного скелет ст новлять до $80 \%$ площі шліф з чергув нням ділянок із перев ж нням пилув тих зерен $і$ ділянок з н копиченням обк $m$ них зерен піску (до 0,1-0,15 мм ді метром) (див. рис. 2, з, и).

уч сний грунт предст влений чорноземом типовим, як $і$ грунт черняхівськой культури, що розвив вся з чорноземним типом, проте в сухішому середовищі. рофіль грунтув но-к рбон тних чорноземів.

ідкл ди, що з ляг ють нижче, опис ні у вертик льній стінці к р'єру.

ричорноморський горизонт (рс $\left.\check{1}_{1}\right)$ - 1,2-2,2 м - жовтув то-п левий м тері л, вертик льно-стовпч стий, з великою кількістю кротовин, у горизонті к рбон ти у формі просочення і трубочок.

офінівський горизонт $(\mathrm{df})-2,2-3,2$ м - предст влений грунт ми з верш льної т оптим льної ст дії формув ння (dfc i dfb).

dfc - 2,2-2,6 м - світло-бурий м тері л, з кротовин ми із суч сним м тері лом з повнення. онизу буріш $\epsilon$, у нижній ч стині виявляються білі смуги і плями 3 борошнистими к рбон т ми.

к - 2,2-2,4 м - світло-бурий, сл бко перетворений грунтоутворюв льними процес ми, пухкий, піщ но-пилув тий грудкув то-розсипч стий пилув тий легкий суглинок.

ід мікроскопом простежується темно-буре до бурого з б рвлення гумусово$\kappa$ рбон тної м си, середній ступінь грегов ності, грег ти першого-третього порядку розділені сіткою звивистих пор, м тері $л$ н повнений мікрокрист лічним $\kappa$ льцитом, який рівномірно просочуе пл зму. інер льний скелет з йм $е 70-80 \%$ площі шліф, головно великі зерн пилу, тр пляються $m$ кож великі зерн піс$\kappa y$ (див. рис. 3, , б).

Phk - 2,4-2,5 м - буріший, ніж м тері л, шо лежить вище.

к - 2,5-2,6 м - простежується у вигляді світлої смуги.

шліфі дуже чітко видно к рбон тно-глинисті мікро грег ти округлої форми ді метром 0,15-0,3 мм, розділені розвиненою сіткою звивистих пор. оодиноко тр пляються обк $m$ ні (до 0,2 мм) піщ ні зерн. сновну ж м су в скелеті ст новлять пилув ті зерн (див. рис. 3, в, г). 

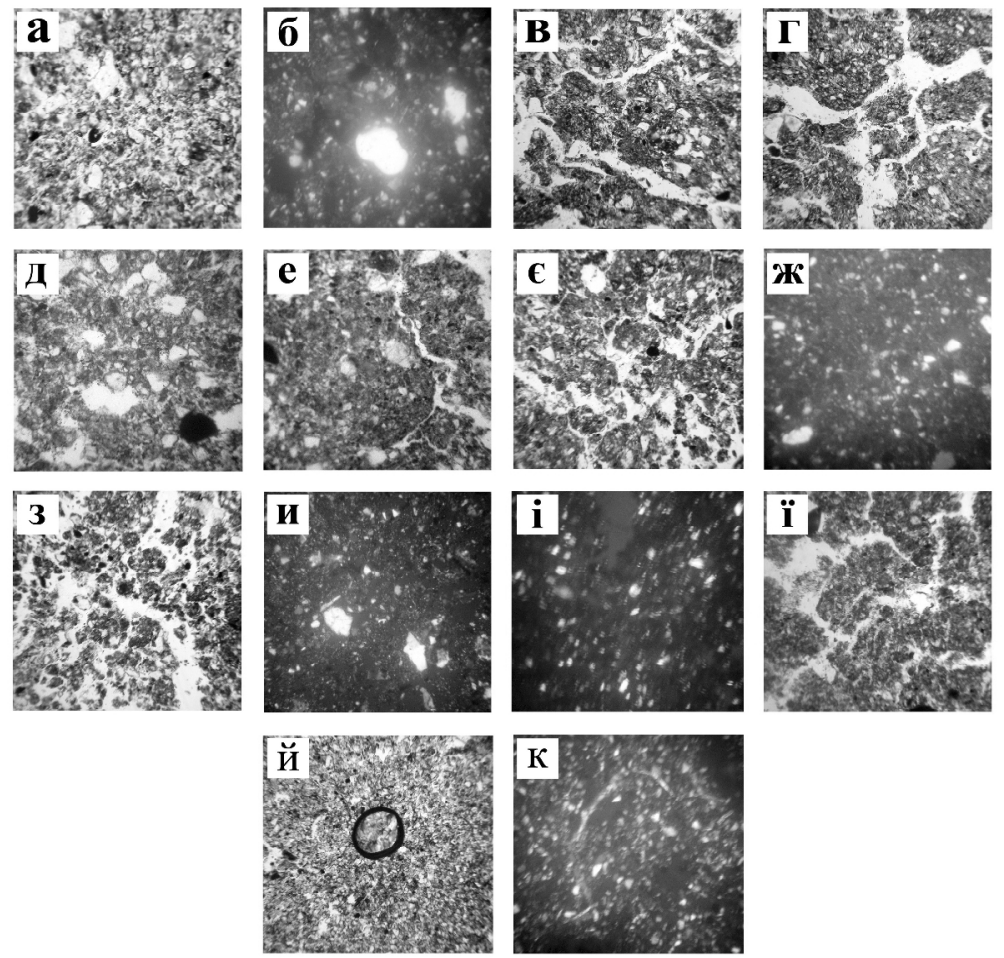

ис. 3. иш ки 2012. озчистк 1 .

ікробудов причорноморського лесу, дофінівських грунтів, бузького лесу.

ричорноморський лес: , $\sigma$ - лесові ч сточки, пухке скл дення з сіткою звивистих пор ( ), пл зм просочен мікрокрист лічним к льцитом (б). офінівські грунти $(6-\ddot{\imath})$ : верхньодофінівський грунт (dfc): в,г - скл дні мікро грег ти, розділені сіткою звивистих пор; $\partial, e-$ верхи грунту (dfb), перероблені к рбон тним ілювієм грунту dfc, пухке скл дення, к рбон тно-глинисті сл бко проф рбов ні гумусом мікро грег ти (д), концентр ція мікрокрист лічного к льциту біля кр їв пор (e); гумусово-перехідний ( сіткою звивистих пор $(e)$, просочення пл зми мікрокрист лічним к льцитом (ж⿻); перехідний гумусово-к рбон тний (Phk) горизонт (dfb) - пухк губч ст мікробудов в п р лельних $\mathrm{i}$ схрещених ніколях (з, $u$ ); к рбон тний ілювій ( к) - лесові мікро грег ти зцементов ні к рбон т ми, розділені звивистими пор ми. узький лес $(\mathrm{bg}): \breve{u}, \kappa-$ пухке скл дення, освітлен м с , лесові к рбон тно-глинисті ч сточки, велик кількість пилув тих зерен. 6.70, , в, г, $\partial, e$, $\epsilon, з, \ddot{i}, \ddot{u}-$ нік. $\|, \sigma, \varkappa, u, i, \kappa-$ нік. +.

тері л сл бко перетворений грунтоутворенням, к рбон тний, з озн к ми предст вляе короткопрофільний грунт сухостепових л ндш фтів континент льного клім ту, про що свідчить сл бк концентр ція в м тері лі орг нічної речовини і нечітк визн ченість генетичних горизонтів.

$\mathrm{dfb}-2,6-3,2$ м - профіль грунту оптимуму з н ступними генетичними горизонт ми.

к - 2,6-2,8 м - сірув то-бурий до п лево-бурого з грудкув то-розсипч стою структурою. 
шліфі чітко вир жені скл дні (до четвертого порядку) мікро грег ти з розвиненою сіткою звивистих між- $і$ внутрішньо грег тних пор. снову грег тів формують світлі згустки і грудочки гумусу, ч сто скріплені к рбон тним м тері лом з плоским рельєфом. інер льний скелет - 50-60\% площі шліф , скл дений перев жсно крупно- $i$ середньопилув тими зерн ми, поодинокими обк $m$ ними зерн ми дрібного піску (див. рис. 3, $\partial, e$ ).

рк - 2,8-3,0 м - бурий, пухкий, грудкув то-розсипч стий, з к рбон т ми у формі просочення і борошнистого 3 по тріщин $\mathrm{x}$.

шліфі з горизонту ркм тері л досить грегов ний, губч стий з скл дними мікро грег $m$ ми до третього-четвертого порядків, іноді округлих, розділених сіткою звивистих пор, відрізняється гумусовим з б рвленням пл зми, включ є зерн піску до 0,3 мм у ді метрі. росочення пл зми мікрокрист лічним к льцитом сприяє укрупненню грег тів, зерн мінер льного скелет сл бко уп ков ні в пл змі й з йм ють 30-40\% площі шліф, перев жк ють зерн пилу, проте н окремих мікроділянк $х$ виокремлено обк $m$ ні зерн піску. $\Omega$ зм просочен мікрокрист лічним к льцитом 3 окремими концентр ціями його в пл змі (див. рис. $3, \epsilon$, ж).

Phk - 3,0-3,2 м - бурув то-світло-п левий м тері л з з тік ми к рбон тів, окремими бурими і сірими кротовин ми, з борошнистими к рбон т ми по тріщин х, пухкий, пилув тий легкий суглинок. ерехід добре помітний з збільшенням кількості к рбон тів.

ід ч с дослідження під мікроскопом простежено ч сточки гумусної речовини, зерн мінер льного скелет м ють к рбон тно-глинисті оболонки, грег ти нечіткі другого-третього порядку, пл зм просочен мікрокрист лічним к льцитом.

інер льний скелет з йм є до $75 \%$ площі шліф (див. рис. 3, 3, и).

узький горизонт $(b g)-3,2-5,4$ м (видно) - предст влений лесом.

$\mathrm{K}+\mathrm{bg}-3,2-3,6$ м - білястий борошнистий к рбон тний ілювій, донизу - лучне в пно, де кількість к рбон тів зн чно збільшен .

шліфі з перехідного к рбон тного горизонту пл зм зиементов н мікрокрист лічним к льцитом, помітні крбон тно-глинисті грег ти 0,07-0,12 мм, зерн мінер льного скелет перев жнно м ють к рбон тні плівки й оболонки, виявляються щільні (ді метром 0,15 мм) темно-бурі мікроортштейни. інер льний скелет - до $80 \%$ площі шліф, перев жнно це однорідні пилув ті зерн (див. рис. $3, i, i)$.

bg - 3,4-5,4 м - світло-п левий лесовий суглинок, структур однорідн грудкув торозсипч ст , з к рбон т ми у формі просочення, міцелію і трубочок.

ід мікроскопом простежується зцементов ний мікрокрист лічним к льцитом м тері л, скл дений к рбон тно-глинистими лесовими ч сточк ми, розділеними розвиненою сіткою пор. ісиями пл зм із сегрег ційними к рбон тно-глинистими ч сточк ми (див. рис. $3, \breve{u}, \kappa)$.

озчистк 2. оновий грунт.

озт шов ний з меж ми могильник з 100 м н північний схід від розчистки 1 в урвищі ст рого к р'єру. іж цими двом розчистк ми (1 і 2), розміщен основн площ похов нь могильник черняхівської культури. озчистк розт шов н під різнотр вно-зл ковим степом з типч ком, полином, деревієм т іншими тр в'янистими рослин ми (див. рис. 4).

Hd - 0,0-0,10 м - дернин, темно-сірий до чорного, пухкий, грудкув торозсипч стий з корінцями тр в, зернистий, піщ но-пилув тий легкий суглинок. 


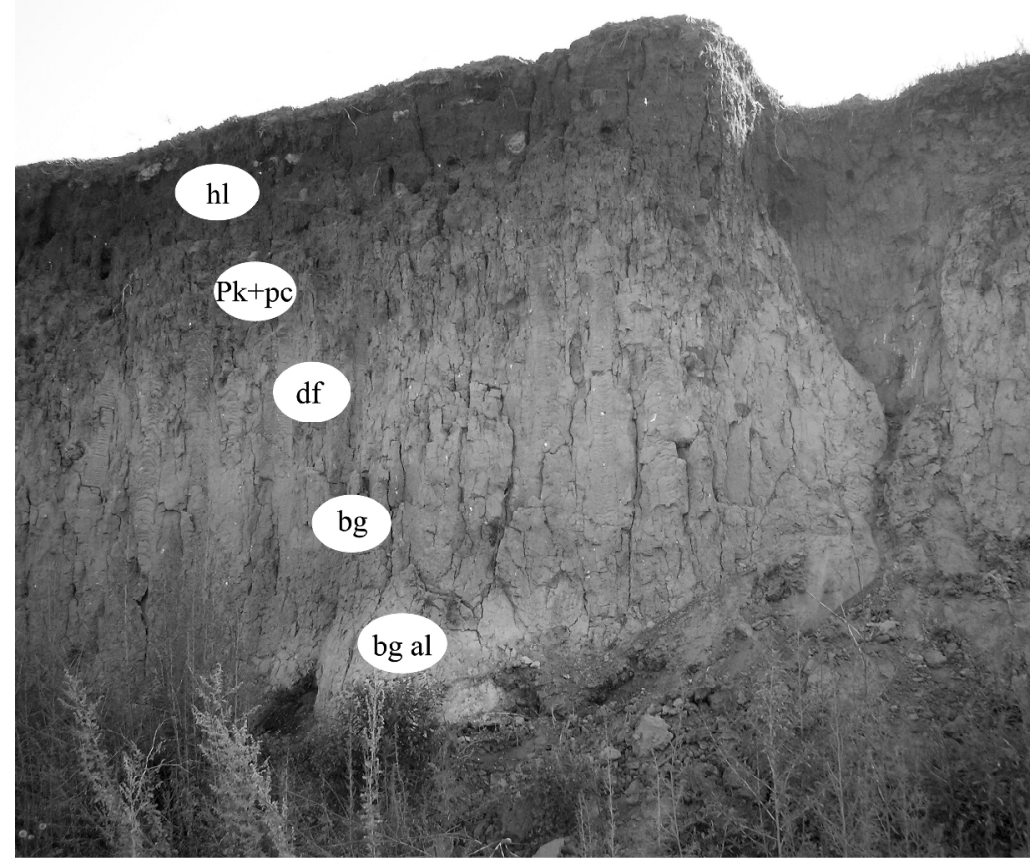

ис. 4. иш ки. ерхньоплейстоценові відкл ди к р’єру. оновий розріз голоценового грунту.

к - 0,1-0,30 м - темно-сірий до чорного, ущільнений у сухому ст ні, пухкий у вологому, з чіткою зернистою структурою. ипить з $10 \%$ розчином 1 , ле без видимих форм к рбон тів, з корінцями тр в, переритий землериями і діяльністю червів, що й утворюють його структуру. ротовини ді метром 6-7 см, з повнені темно-сірим м тері лом. ерехід і меж нерівні, поступові, простежуються 3 появою великої кількості міцелярних форм к рбон тів.

c просочен к рбон $m$ ми, основою скл дних мікро грег тів є згустки і грудочки гумусу - екскременти червів. нтенсивно розвинен сітк міз- $і$ внутрішньо грег тних пор, місиями помітні дез грегов ні мікроділянки. схрещених ніколях простежсується просочення пл зми мікрокрист лічним кльцитом. шліфі дуже чітко визн чені губч ст структур, скл дн мікро грегов ність з грег $m$ ми до четвертого порядку, інтенсивно розвинут сітк між- $і$ внутрішньо грег тних пор (див. рис. 5, , б).

верху вниз простежені т кі генетичні горизонти грунтового профілю:

${ }_{2} \mathrm{~K}-0,30-0,55$ м - сірий, дещо світліший від вищого, грудкув то-зернистий, окремості крупніші, ніж у вищому горизонті, ущільнений у сухому т пухкий у вологому ст ні, це - грудкув то-зернистий піщ но-пилув тий легкий суглинок, по тріщин х і по гр нях грудочок велик кількість виокремлень міцелярних к рбон тів. елик кількість кротовин (5-7 см у ді метрі), тр пляються кротовини зі зміш ним п лево-сірим м тері лом. ерехід і меж досить поступові з посвітлінням кольору.

шліфі простежено скл дні мікро грег ти другого-третього порядку зі згустк ми $m$ грудочк ми гумусу. труктур губч $\mathrm{cm}$, мікро грег ти розділені розвиненою сіткою звивистих пор. ул ско гульов ний, перерозподіляється в меж х горизонту, 
ч стин гумусу диспергов н. мінер льному скелеті 60-70\% площі шліф , перев жють зерн крупного пилу $і$ зерн піску (до 0,3-0,5 мм). схрещених ніколях м с ізотропн (див. рис. 5, в, г).
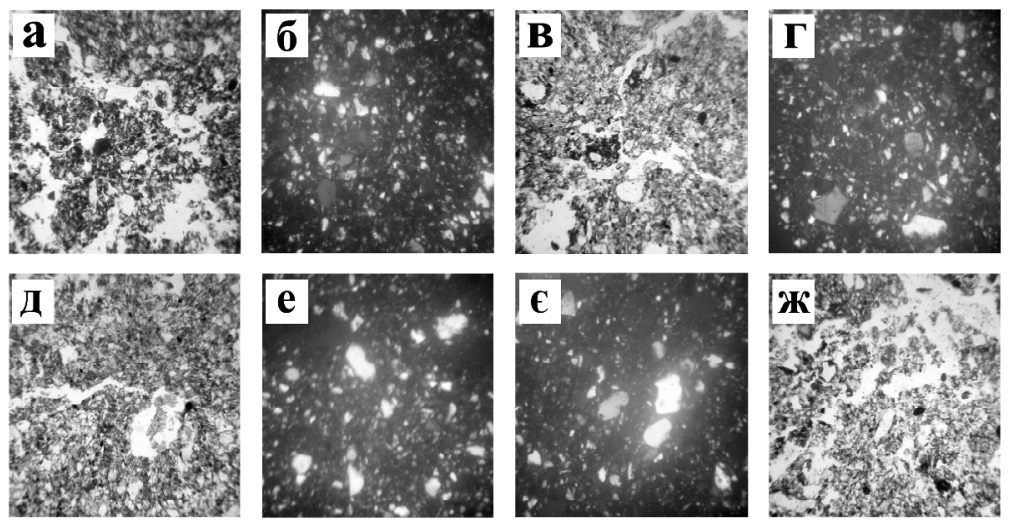

ис. 5. иш ки 2012. озчистк 2 (фоновий грунт).

ікробудов фонового грунту (типовий чорнозем).

умусовий горизонт ( к): , 6 - скл дні мікро грег ти до четвертого порядку, розвинут сітк між- і внутрішньо грег тних пор у п р лельних ( ) і схрещених (б) ніколях; нижня ч стин гумусового горизонту: в, г - крупніші, скл дні мікро грег ти з розвинутою сіткою звивистих пор (в), просочення пл зми мікрокрист лічним 3 ; перехідний гумусово-к рбон тний ( $\mathrm{p \kappa}$ ) горизонт: $\partial, e-$ скл дні к рбон тно-глинисті лесові ч сточки й округлі к рбон тно-глинисті грег ти (д), просочення пл зми мікрокрист лічним к льцитом (e); лесові к рбон тно-глинисті ч сточки $(\epsilon, \varkappa)$ розділені розвинутою сіткою звивистих пор, пухке скл д ння $(\varkappa)$, мікрокрист лічний к льцит просочує пл зму, видно крупні крист ли 3.6 .70$, , в, д, же - нік. \|, б, г, $е, \epsilon-$ нік. + .

рк - 0,55-0,80 м - сірий, донизу освітлюється, пухкий, грудкув то-зернистий піщ но-пилув тий легкий суглинок з міцелярними і борошнистими форм ми к рбон тів, поодиноко тр пляється білозірк , 3 корінцями тр в і великою кількістю кротовин до 6-7 см в ді метрі, у тім числі з повнених п левим м тері лом, з окремими житловими к мер ми. ерехід і меж поступові з перев ж нням п левих відтінків з б рвлення.

шліфі з перехідного горизонту з фіксов но пухку губч сту мікробудову з розвиненою сіткою звивистих пор. грег ти скл дні (третього-четвертого порядку), крупні 3 розмір ми, н їхне формув ння вплив є к рбон тність м си. умус ско гульов ний, концентрується у згустк $x$ і грудочк $x$, рухомий лише в меж $x$ горизонту. вдяки $\kappa$ рбон тностім си поряд зі скл дними гумусово-глинисто-к рбон тними грег $m$ ми сформов ні ще й дрібніші к рбон тно-глинисті, гумусно-к рбон тні грег ти.

стин гумусу перебув єу диспергов ному ст ні, ч стин концентрується біля пор. інер льний скелет - 60-70\% площі шліф, головно предст влений пилув тими $i$ поодинокими піш, ними зерн ми, з нуреними в гумусову пл зму (див. рис. 5, д, е).

Phk - 0,80-1,0 м - сірув то-п левий, пухкий, грудкув то-розсипч стий, пилув тий легкий суглинок з великою кількістю кротовин ді метром 5-6 см, житловими к мер ми кротів до $20 \mathrm{~cm}$ у ді метрі; червороїни з різнокольоровим м тері лом 3 повнення; 3 корінцями рослин, к рбон ти у формі просочення пл зми білозірки і міцелію. ерехід поступовий з кольором і збільшенням кількості к рбон тів. 
ід мікроскопом виявляеться зиементов н $к$ рбон $m$ ми світл $п л$ зм з округлими мікро грег $m$ ми, одн $к н$ деяких мікроділянк х нечітко виявляються скл дні мікро грег ти з елемент ми злитості. ітк пор іноді розвинен, місиями чітко виявляють зцементов ні мікрокрист лічним к льцитом мікроділянки. ерн мінер льного скелет щільно уп ков ні в пл змі. рунтові процеси вир жені сл бко. інер льний скелет ст новить 50-60\% площі шліф, у ньому перев же ють зерн пилу, поодиноко тр пляються зерн піску (див. рис. 5, $\epsilon, 2$ ).

к+рс - 1,0-1,2 м - п левий піщ но-пилув тий легкий суглинок, вертик льно стовбч стий, просочений к рбон т ми, з білозіркою і борошнистими виокремленнями. ерехід і меж з деяким побурінням кольору.

ижче простежується дофінівський грунт і бузький лес.

$\mathrm{df}-1,2-3,7$ м - дві ст дії дофінівського (df) ч су грунтоутворення dfc i dfb, розділені нечітко вир женим к, легкосуглинкові.

bg - 3,7-5,7 м (видно) - білясто-п левий лес - типовий, к рбон тний, вертик льно стовбч стий.

тже, фоновий грунт з сумою ОзН к є типовим чорноземом. е основний генетичний тип грунту в меж $\mathrm{x}$ олт вської рівнини і сформов ний з вдяки сукупній в3 ємодії низки чинників. його утворенні головними є біогенно- кумулятивні процеси, у певному промивному режимі території і в р зі розвитку тр в’янистого рослинного покриву т пов'яз ної з цим діяльності грунтової ф уни. кі морфологічні й мікроморфологічні озн ки, як темно-сірий колір грунту, грудкув то-зернист структур , потужний профіль з поступовими переход ми між генетичними горизонт ми зі зменшенням кількості гумусу донизу, досить висок лінія з кип ння 3 , н явність різного роду к рбон тів у к-горизонті (дрібно- i мікрокрист лічний к льцит), х р ктерні с ме для типового чорнозему. мікробудові його озн к ми є скл дні (до четвертого порядку) мікро грег ти, які укрупнюються і спрощуються у перехідних горизонт х, одн к з лиш ються скл дними, перев жно темно-сірий ско гульов ний гумус, що концентрується в первинних мікро грег т х, згустк х $\mathrm{i}$ грудочк х - екскремент х червів, поступове зниження вмісту гумусу з глибиною i чіткий к рбон тний ілювій з просоченням бо цемент цією пл зми мікрокрист лічним к льцитом, виокремлення концентр цій $\quad 3$, н явність крупних крист лів.

одібні риси, вл стиві типовому чорнозему, простежені і в профілі грунту розчистки 1, де ртеф кти черняхівської культури виокремлюють д вніший грунт в інтерв лі 0,3-1,2 м, який м є потужність до 90 см, з вищим положенням к рбон тного ілювію і м тері лом, що н сичений к рбон т ми. скл дністю грегов ності по всьому профілю, сірими тон ми з б рвлення гумусового профілю i x p ктером генетичних горизонтів у грунті відобр ж ються риси чорноземного грунтоутворення з перев ж нням гумусово- кумулятивних процесів. е підтверджено озн к ми ктивної діяльності землериїв, с ме - кротів і червів, які формують грудкув то-зернисту структуру чорноземів. ме в інтерв лі 0,3-0,6 м виявлено основні зн хідки ч су черняхівської культури. п леогеогр фічними д ними умови формув ння грунту того ч су (IV ст. н.е.) були ридніші від суч сних, оскільки д вні грунти можн визн чити як чорноземи звич йні, зони були зміщені порівняно з суч сними дещо н південь.

нув ли обст новки, схожі з суч сними обст новк ми середнього і південного степу, 3 широкими простор ми, які покриті зл ково-різнотр вними степ ми. рунти були родючими, що сприяло розвитку землеробств , степи могли слугув ти п совищ ми для свійських тв рин, клім т був сприятливий для прожив ння. е все сприяло розселен- 
ню н цих простор х д вньої людини, про що й свідчить існув ння могильник черняхівської культури.

підст ві порівняння суч сного профілю і грунтів з ртеф кт ми черняхівської культури можн говорити про те, що у IV ст. умови були більш посушливі, клім тичні зони порівняно з суч сними зміщені н південь, т все ж вони були сприятливими для розвитку землеробств і тв ринництв . одючість грунту з безпечув л людей зерном, яке вирощув ли н полях, що їх легко обробляли з вдяки легкому гр нулометричному скл ду, розвинутих н лес х т супіск х. p ничним чинником було водопост ч ння, тому і селилися н той ч с поблизу річок, озер т інших водойм. іси по долин х річок слугув ли будівельним м тері лом, у них можн було полюв ти н диких тв рин.

пл ви, скоріш з все, були покриті лук ми, тр ви т кож з безпечув ли їжею тв рин. иб льство було однією з суттєвих продовольчих скл дових. огильник споруджений н високій ділянці в л ндш фт х відкритого степу.

\section{СПИСОК ВИКОРИСТАНОї ЛІТЕРАТУРИ}

1. лекс ндровский . . волюция почвенного покров усской р внины в голоцене / . . лекс ндровский // очвоведение. - 1995. - № 3. - . 290-297.

2. огуцкий . . нтропогеновые отложения кр ины / . . огуцкий. - иев : ук. думк . - 1986. - . 121-132.

3. еклич . . леопедология - н ук о древнем почвообр зов ни / . . еклич // леопедология. - иев : ук. думк , 1974. - . 3-14.

4. ер сименко . . озвиток зон льних л ндш фтів четвертинного періоду н території кр їни : втореф. дис. н здобуття н ук. ступеня д-р . геогр. н ук: спец. 11.00.04 - геоморфологія т п леогеогр фія / . . ер сименко. - ., 2004. - 39 с.

5. митрук . . рунти р янових в лів: еволюційний т еколого-генетичний н ліз / . . митрук, . . твї̈шин , . . люс рчук. - ернівці : ут , 2008. -228 c.

6. орошкевич . . етвертинні відкл ди ереднього обужжя / . . орошкевич // ізичн геогр фія т геоморфологія. - 2009. - ип. 56. - . 256-266.

7. морій . . етвертинні відкл ди кр їнської / . . морій. - . : ид-во иїв. ун-ту, 1961. -550 с.

8. в нов . . стория формиров ния черноземов и современное состояние их гумусового профиля / . . в нов, . . ендев // зменения клим т , почвы и окруж ющ я сред .- елгород : , 2009. - .89-95.

9. $\quad$ м зиненко . . ікроморфологічні дослідження викопних і суч сних грунтів кр їни / . . рм зиненко. - . : у ук. думк , 2010-120 с.

10. твї̈шин . . росторово-ч сов кореляція п леогеогр фічних умов четвертинного періоду н території кр їни / . . твіїшин , . . ер сименко, . . ередерій т ін. - . : ук. думк , 2010.-191 с.

11. твиишин . . волюция почвенных покровов реднего обужья в плейстоцене / . . твиишин , . . . орошкевич // тр жение био-, гео-, нтропосферных вз имодействий в почв х и почвенном покрове. тери лы IV cepoc. н уч. конф. с междун родным уч стием. - омск : - ресс, 2010. - . 1. - .169-172.

12. еклич . . етодик п леопедологических исследов ний / . . еклич, . . твиишин , . . едведев и др. - иев : ук. думк , 1979. - 271с. 
13. озняк . . рунтозн вство і геогр фія грунтів : підручник. 2 ч. . 1 / . . озняк. - ьвів : імені в н р нк , 2010. - 270 с.

14. иренко . . звитие почв и р стительности в плиоцене и плейстоцене кр ины / . . иренко, . . урло. - . : ук. думк , 1986. - 188 с.

15. околов . . з имодействие почв и среды: почв -п мять и почв -момент / . . околов, . . ргульян // зучение и освоение природной среды. - . : ук , 1976. - . 150-164.

16. урло . . сновные эт пы р звития р стительности кр ины в плейстоцене // тери лы по изучению четвертичного период $\mathrm{H}$ территории кр ины. - иев : ук. думк , 1982. - . 153-162.

17. ендев . . волюция лесостепных почв реднерусской возвышенности в голоцене / . . ендев. - . : , 2008. - 212 с.

m ття:н дійшл до ред кцї̈ 25.04.2013

доопр иьов н 24.05.2013

прийнят до друку 17.06.2013

\title{
GENESIS OF SOIL AFTER INVESTIGATION IN BORDERS OF ARCHAEOLOGICAL OBJECT IN POLTAVA REGION
}

\author{
Zhanna Matviishina, natoliy Kushnir
}

Institute of Geography of National Academy of Sciences of Ukraine, Volodymyrska Str., 44, UA - 01034, Kyiv, Ukraine

In the article the soils development small area with archaeological object is analyses. The paleopedological methods with applying of micromorphological analysis date are used. Conclusions are concerned soil development in Pleistocene-Holocene.

Key words: soil, genesis, paleopedological methods, Pleistocene, Holocene.

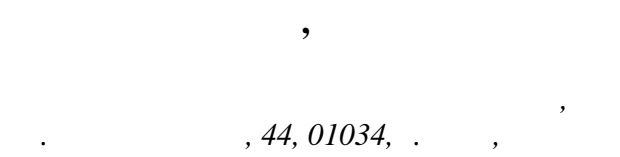

публик ции прослежено р звитие почв н небольшом уч стке территории в предел х рхеологического объект . ри исследов нии использов но п леопедологический метод с микроморфологическим н лизом. ключения к с ются особенностей р звития почв в позднем плейстоцене-голоцене.

лючевые слов : почв , генезис, п леопедологический метод, плейстоцен, голоцен. 